\title{
Tehnologia comunicării și impactul său cultural, social și religios
}

\author{
Cătălin Marius RESCEANU*
}

\begin{abstract}
Technologies of comunication is continuously improving, new sistem, new means and new instrument of comunication and interaction emerge, which, on the one hand have the capacity to synthetisize the production of informations and images and, on the other hand, to interact with the proposing the informativ material. This is the reason why nowadays there has been a debate on the ethics of comunication. We ca state that the ethics in and morally approaching every act, either individual or collective, that lead to a responsibl use of liberty of expression. Despite these challenges, the Church understood the necessity of mass media for the modern individual. Thus, the Romanian Orthodox Church has taken this responsibility and is present in the space of public communication and visibility.
\end{abstract}

Keywords: new technologies, communication, traditional media, liberty of expression, mission, digital media, network.

\footnotetext{
*PhD Candidate, Faculty of Orthodox Theology at „1 Decembrie 1918" University in Alba Iulia, Romania.
} 


\section{Preliminarii}

Atunci când vorbim despre tehnologie, cu siguranță ne gândim la ceva nou, ceva care răspunde sau se adresează unei societăți moderne, care este într-un acord deplin cu inovația. Este foarte adevărat că această schimbare și transformare este într-o continuă mișcare. Comunicarea se afla și ea sub presiunea acestor transformări ale modernității, se vorbește frecvent despre ,noile media”, despre „,noua comunicare de masă", acestea fiind un răspuns firesc al necesităților unor persoane sau grupuri de persoane mai mult sau mai puțin omogene din punct de vedere social, cultural sau religios, care au concepții, valori, principii comune. Noua comunicare reușește să ofere maselor largi accesul la informație, aceasta fiind componenta principală a comunicării, o comunicare care ridică însă multe semne de întrebare, datorate faptului că se simte cu ușurință o lipsă acută de conținut. Comunicarea făcută de dragul de a fi făcută, slăbirea relațiilor interumane, conflictele mediatice, manipularea și lipsa unei etici a comunicării se constituie în a fi astăzi factori de slăbiciune a noilor media. Mai mult, legat de aceste afirmații, nu putem despărți cultura de „noile media”, de „noua comunicare" deoarece aceasta dă identitate comunicării, conferă un bun sens prin valorile moștenite, prin tradiții, caracteristici ale grupului social... Exigența vitală a omului modern este de a se fi informat, de a se îmbogăți cultural, de a relaționa într-o societate diversificată, supusă permanent transformărilor tehnologice.

Revoluțiile tehnologice se află în stadii diferite de schimbare sau transformare, mai exact noile media nu au reușit în totalitate să înlocuiască vechile media încă în uz multe dintre acestea (radioul, televiziunea, presa scrisă, cinematograful). Istoria comunicării confirmă faptul că este vorba despre un curs evolutiv al omului din punct de vedere al transmiterii de mesaje, de la simple articulații sonore sau zgomote până la ceea ce numim astăzi „rețele telematice”.

\footnotetext{
${ }^{2}$ Cf. Manuel Castells, Galassia Internet, Saggi Universale Economia Feltrinelli, 2006, p 124.
} 
Progresul tehnologic științific și dezvoltarea economică şi culturală modifică mijloacele de comunicare sociale prin intermediul celor mai importante elemente ale acesteia: coduri, sisteme, tematici, conținuturi, instrumente (aparate) etc. Tehnologia a avut de-a lungul timpului un obiectiv foarte bine definit, și anume, acela de a oferi o comunicare deplină, de a transmite clar mesajul, informaţia deținută, nu a avut în vedere înnoirea unor instrumente tradiţionale de comunicare ci tocmai de a pune la dispoziție sisteme optime pentru a transmite informații la masele largi. Este necesar să subliniem un aspect foarte important în legătură cu dezvoltarea tehnologiilor comunicării si anume, „faptul că acestea, și în special cele informatice, au modificat profund modalitățile de interacțiune între persoane și instrumentele utilizate"

În studiul de față nu vom despărți cei doi termeni, deja folosiţi, schimbare si transformare, pentru că cei doi termeni ating domenii diferite de interes. Dezvoltarea noilor tehnologii în lumea comunicării a produs multe transformări atât din punct de vedere socio-cultural cât și din punct de vedere semiotic. Înfățișarea și prezentarea noilor tehnologii nu seamănă deloc cu cea tradițională, acceptarea de către diferite persoane, grupuri sau mase de persoane se face într-un mod diferit, așadar instrumentul tehnologic care oferă informație devine un ,instrument indispensabil pentru a garanta libertate si progres într-o societate si mai globală"’.

Tehnologia modernă are două calități definitorii, oferind o comunicare sintetică și în același timp interactivă. Cele două elemente schimbă total înfățișarea vechilor mijloace de comunicare în masă. Comunicarea sintetică se referă la capacitatea de a da naștere unor noi cuvinte, care sunt folosite pentru a transmite mai multe elemente prin intermediul unui singur cuvânt: exemplu morfemele (substantive,

\footnotetext{
${ }^{3}$ Franco Lever, Pier Cesare Rivoltella, Adriano Zanacchi, Nuove Tecnologie della comunicazione, în Dizionario di scienze e tecniche, Roma, Elledici, Rai, Eri, 2002, p 818.

${ }^{4}$ Ibidem.
} 


\section{Cătălin Marius RESCEANU}

verbe, afixe. etc.) sunt combinate pentru a da naștere unor cuvinte noi, „comunicandovele” (în italiană) care înseamnă: în timpul comunicării acestora, vouă..$^{5}$ În cuvântul prezentat există trei cuvinte distincte: comunicare, aceleia și vouă.

Omul postmodern, aflat sub presiunea timpului și a spațiului, este supus unei mișcări continue. Există o realitate uimitoare în ceea ce privește continua mișcare a omului modern, cel care transformă lumea datorită globalizării într-un ,orizont domestic”6 și anume, acesta reușește să se integreze unor cerințe date de societatea multiinformațională, consumistică și secularizată, fără a depune vreun efort exagerat. Am pomenit mai sus și despre un alt element al comunicării, datorat tehnologiei moderne, si anume interactivitatea. Mobilitatea mijloacelor media și hipercomunicarea, de care ne folosim astăzi, îi conferă omului postmodern posibilitatea de a interacționa întrun context clar marcat de timp si spațiu. Se vorbește adesea despre faptul că în zilele noastre se citește tot mai puțin însă, dacă luăm un exemplu din lumea internetului și anume postarea unor materiale scrise pe blogul personal, descoperim în urma unor statistici că, există în lume aproape 160 de milioane de bloguri. Raportat la populația lumii, acest număr ne indică faptul că avem de a face cu un blog la 42 de persoane, așadar cu siguranță suntem foarte aproape de vremurile în care scriam cu toții pentru a putea comunica. ${ }^{7}$ Un alt exemplu, legat de cele afirmate mai sus, este și publicitatea. Aceasta a căpătat în epoca modernă și în cea postmodernă anumite calități de mobilitate, încât timpul și spațiul se transformă în elemente indispensabile. Publicitatea dă răspuns dorințelor omului modern, ea are ca fundament condiția de a răspunde, de a face si de a ajunge peste tot. Mai mult, publicitatea este capabilă să atragă, să implice, să seducă, să convingă

${ }^{5}$ Ro.wikipedia.org/wiki/limba_sintetica.

${ }^{6}$ Giorgio Triani, Il futuro e adesso, Societa mobile e istantocrazia, Torino, Ed. San Paolo, 2013, p. 51.

${ }^{7}$ Cf. Unesco, congresul, Blog e blogger în lumea în mișcare, Marsilia, 3 martie 2012. 
și să împingă spre consum. ${ }^{8} \mathrm{Nu}$ de puține ori auzim la radio, sau vedem la televizor sau pur și simplu citim pe un panou publicitar, despre un anume lucru care devine o lume care se mișcă cu tine, sau te însoțește, îți devine partener de viață sau tovarăș în călătorie. Însă un lucru paradoxal, concret, dar și real în același timp, ne confirmă faptul că publicitatea se poate mișca doar când este fixă, când stă pe loc. Mișcarea noastră fizică sau cu mașina definește starea sau poziția noastră raportată la anumite lucruri. Omul dinamic, în mișcare, poate crea o stare activă mobilă pentru manifestul publicitar, ajutat de spațiul nostru, pentru o anumită perioadă de timp. Rapiditatea cu care se ajunge de la dorință la achiziționare, a devenit astăzi foarte scurtă, se vorbește în termeni de specialitate despre: ,atingerea rapidă cu degetul a unui ecran" ${ }^{\prime}$ web marketing. Prin intermediul celor două exemple putem observa cu foarte mare ușurință faptul că trăim în postmodernitate, într-o societate mobilă, o societate activă, vie din punct de vedere comunicativ.

Tehnologia a atins în zilele noastre cote neatinse, fizicianul Alwin Weinberg numește această epocă postmodernă a revoluției tehnologice „,big science”, afirmând totodată și faptul că astăzi trăiesc în lume mai mulți oameni de știință decât suma tuturor oamenilor de știință care au trăit înainte, în arcul întregii istorii a umanității”'10. Există însă un element foarte important care ridică multe probleme la nivel mondial în era postmodernității, şi anume limita sau măsura lucrurilor. Nu putem lăsa de-o parte rapiditatea și puterea care sunt participanți activi ai noilor tehnologii, de altfel binomul „putere și rapiditate pune în evidență prin transformări rapide tehnologia informatică și telecomunicațiile"

\footnotetext{
${ }^{8}$ Cf. Adriano Zanacchi, Pubblicita, Effetti Collaterali, Roma, Editori Riuniti, 2004, p 9.

${ }^{9}$ Giorgio Triani, op. cit, $\mathrm{p} 60$.

${ }^{10} \mathrm{P}$. Greco, Cibo per la mente, newsletter di Fondazione IDIS Citta della Scienza, 16 ottobre 2012.

${ }^{11}$ Cf. G. Triani, op. cit., p 71
} 
Societatea secularizată postmodernă este o societate a accesului dar în același timp și una a excesului, sensul măsurii sau al limitei fiind mereu pus la încercare. Riscul privește în primul rând ceea ce este definit ca „timp real”. Există o inerție a unui progres firesc dat de ritmul tehnologiei, însă nu vom putea vreo data să confundăm 24 de ore de transmisie cu 36 de ore. Cei care se definesc ca „tehnofili” sunt plini de optimism și exuberanța datorită tuturor cuceririlor tehnologice însă, este foarte important ca noi, cei care ne folosim de toate aceste facilități ale tehnologiei, să vedem anticipând corect riscul unor „vieți multiple în rețea” sau „existența în tranzit”" în lucrarea „The Technological System” vorbește despre faptul că tehnologia actuală nu mai poate fi concepută ca un simplu instrument ci ca un mediu. În societatea postmodernă relațiile interumane sunt mediate, oamenii nu se mai întâlnesc față către față, tehnologia ca mediator generează un mediu diferit de cel natural în care oamenii trăiau într-un anumit firesc. Totul se realizează într-o mare viteză, într-un ritm foarte accelerat în care omul simte, prin intermediul tehnologiei, un lucru impus. Se poate vorbi foarte clar despre o mare suferință a comunicării și a comuniunii, omul postmodern se găsește într-o situație foarte delicată datorată faptului că simte o creștere a singurătății personale, trăiește într-o lume globalizată din toate punctele de vedere ale comunicării. Tehnologia devine pentru om un însoțitor permanent care-l susține, îl ajută să fie integrat în această lume, pentru care el este parte eficientă. ${ }^{13}$

Oamenii au diverse obiective în viața lor însă, acestea alcătuiesc viața socială, în cadrul căreia putem vorbi despre nevoi solide, acestea fiind satisfăcute de tot ceea ce noi numim produs media. În postmodernitate omul iese din privatul sau, expunându-se în numele socializării, a comunicării în rețea, fără să cunoască dimensiunea

${ }^{12}$ Cf. G. Triani, op. cit., p 77

${ }^{13}$ Cf. Jacques Ellul, The Technological System, New York, Contunuum Publishing Corportaion, 1980, p 38. 
limitei. Creatorul wikileaks, Julian Assage, spunea despre facebook că este „cea mai înfricoșătoare mașină de spionaj existentă”|14. Întâlnirile virtuale riscă să creeze multă confuzie în rândul celor care le utilizează, ele fiind în defavoarea întâlnirilor față către față. Este foarte adevărat că mult mai ușor comunici mediatic însă comunicarea nu este completă, deoarece omul are resurse, calități și mijloace necunoscute și nebănuite pentru a comunica în mod deplin. Deseori încercăm să înțelegem contextual, de ce comunicarea stă într-o legătură permanentă cu comuniunea. Ne întrebăm: Ce au cele două în comun?, Ce le atrage?, Ce le face să fie în multe situații date de nedespărțit? Comunicarea personală este supusă unui mare pericol din punct de vedere social, deoarece cele trei ambituri tradiţionale: familia, prietenii și cunoscuții nu reușesc să satisfacă măsura cererii comunicative dată de tehnologia modernă. Pentru a înțelege mai bine cele afirmate anterior, ne vom folosi de un exemplu care este la îndemâna tuturor, și anume relațiile de prietenie. Raportul prieteniei în carne și oase pentru un tânăr student poate fi de patru sau cinci persoane, în timp ce prin rețelele de socializare tip facebook poate fi de 130 de prieteni. Este o diferență covârșitoare, însă ne întrebăm dacă relațiile de prietenie nu au suferit anumite modificări din punct de vedere cultural și social?

Societatea globalizată poate fi unul dintre răspunsurile la aceste probleme, pe care tehnologizarea mijloacelor de comunicare în masă le provoacă. Folosim frecvent cuvântul ,globalizare” el fiind de altfel unul dintre cuvintele magice ale erei moderne și postmoderne. Într-o lume complexă prin ,globalizare se înțelege mișcarea care determină în societatea modernă o unificare accentuată a diferiților factori economici, financiari, culturali, politici sau de orice altă natură"15. Globalizarea are ca scop principal unificarea tuturor forțelor menționate mai sus,

\footnotetext{
${ }^{14}$ G. Triani, op. cit., p. 76.

${ }^{15}$ Pr. Conf. Teofil Tia, Globalizarea- elemente de Teologia Economiei, Alba Iulia, 2009, p. 3.
} 
acest lucru realizându-se în urma unui proces de lungă durată, un proces dinamic, de uniformizare. Între această uniformizare, ca efect al globalizării și dezordinea mondială este o distanță foarte mică și sensibilă. Și din punct de vedere al comunicării, globalizarea devine una dintre caracteristicile importante ale acesteia, deoarece tendința este de răspândire, de a cuprinde lumea întreagă. Vorbim frecvent despre spațiu și timp, două elemente care sunt indispensabile globalizării. Lumea postmodernă se mișcă într-un ritm frenetic, într-o permanentă schimbare de viteză cuprinzând locuri foarte îndepărtate. „Organizarea spațiului si a timpului, datorată dezvoltării mijloacelor media, este unul dintre aspectele fundamentale ale celor mai cunoscute procese care au transformat lumea modernă"' ${ }^{\prime \prime}$. Globalizarea, în mod evident, este una dintre caracteristicile principale ale lumii moderne. $\mathrm{Nu}$ putem să indicăm exact apariția acesteia în societatea modernă, literatura de specialitate vorbește despre ,prima modernitate”, care este indicată la sfârșitul evului mediu, datorată dezvoltării comerțului. Iată cum se explică astăzi, într-o lume secularizată, faptul că, globalizarea ne împinge spre un lucru clar: „,̂mpreună” ${ }^{\prime 17}$, spre o viziune globală a vieții sociale, culturale și religioase. Este foarte adevărat că putem realiza împreună foarte multe lucruri, putem să ne bucurăm împreună, putem învăța împreună, putem comunica, putem transmite și am putea continua aceste exemple de lucruri făcute împreună, care pe scară globală au devenit o caracteristică normală a vieții sociale. Această viziune globală a comunicării poartă însă foarte multe riscuri, care-1 pot transforma pe omul postmodern, secularizat într-un consumator de produse de toate tipurile: cultural, economic, social, comunicațional și chiar religios. Globalizarea produce în era postmodernă un ,imperialism cultural"18, care este pe cale să dea naștere unei forme de subordonare a culturilor tradiționale, invadate de valori noi propuse prin mijloace de comunicare în masă. În termeni

\footnotetext{
${ }^{16}$ F.B. Thompson, Mezzi di comunicazione e modernita, Bologna, Il Mulino, P. 211.

${ }^{17}$ Ibidem, p. 224.

${ }^{18}$ Ibidem, p. 232.
} 
concreți, această invazie s-a produs prin exportarea programelor comerciale propuse mai întâi de Statele Unite ale Americii iar mai apoi de către țările puternic dezvoltate. Modelul propus prin intermediul acestor programe mediatice s-a răspândit cu foarte mare ușurință, provocând transformări uriașe în rândul societăților tradiționale. Dacă ar fi să ne oprim la numai câteva din exemplele pe care le întâlnim în viața de zi cu zi, observăm transformări majore: consumul de bunuri, educație mediatică, viitor actual, fără trecut si prezent.

Dezvoltarea tehnologiei are contribuția sa în conturarea globalizării comunicării, vorbim aici despre sistemele, rețelele terestre, utilizarea sateliților de comunicații si nu în ultimul rând de digitalizarea informației și tehnologiile electronice sau microprocesoarele. Informația este prezentă peste tot în lume prin intermediul noilor tehnologii, prezenţă la scară mondială a acesteia reprezentând una dintre caracteristicile definitorii ale comunicării în era postmodernă.

Într-o lume tehnologizată, în care omul postmodern se simte în măsură să cucerească orice nivel de cunoaștere, există un mare deficit în ceea ce privește comunicarea directă, ,mărturisirea”. Impactul pe care noile media, tehnologia postmodernă îl are asupra religiei este unul evident, sistemul preceptelor religioase fiind supus unor presiuni foarte puternice. Evoluția mijloacelor de comunicare în masă a creat o societate globalizată, în care libertatea este trăită sub forme de agresiune în foarte multe situații. Limita normalului s-a transformat in abuz, omul postmodern având la îndemână instrumentele necesare pentru a se exprima liber, fără să fie oprit. Adevărul nu mai este o năzuință a omului postmodern, el se simte eficient într-o societate globalizată cultural și social și nu în ultimul rând chiar religios. Viața Bisericii este una vie, activă, ea trebuie să se transforme în creatoare de cultură pentru a avea o societate sănătoasă bazată pe principii si valori. Societatea postmodernă este lipsită de noblețe, ea nu mai creează cultură, aceasta se împrumută, sau se mută cu rapiditate, 
cu ajutorul tehnologiei dintr-o parte a lumii în cealaltă. Omul, prin așezarea sa, a fost un creator, i-a plăcut să intervină în lucrarea naturii și să creeze el însuși. Comunicarea Bisericii este pentru mărturisirea adevărului și cu ajutorul culturii și a civilizației, folosindu-se de descoperirile tehnologice. Măsura folosirii acestora o dă maturitatea cu care fiecare om înțelege care sunt limitele, unde este granița care delimitează buna măsură de abuz. Valorificarea înțeleaptă a noilor media poate fi un mijloc și un instrument unic de mărturisire a Bisericii. Progresul tehnologic face parte din viața culturală, socială și religioasă a postmodernității, fiecare din reușitele cercetării din domenii diferite ajutându-ne să înțelegem mai bine natura lor.

\section{Concluzii}

Dezvoltarea rapidă a noilor media a condus la rezultate neașteptate, pe care astăzi, prin intermediul acestora, omul postmodern le aduce în viața de zi cu zi, ele intră într-un ritm firesc, la muncă, în studiu, cercetare, artă sau divertisment.

Cuvântul lui Dumnezeu poate fi transmis oriunde în lume prin intermediul acestor tehnologii. $\mathrm{Cu}$ ajutorul acestora se poate împlini misiunea Bisericii de a transmite adevărurile sale, cuvântul plin de energia divină îl poate revigora spiritual, îl poate vindeca pe omul modern aflat în suferință. Pomenind de globalizare în acest cadru al noilor media, cu siguranțăputem spune că Ortodoxiapoatefipromovată prin intermediul mijloacelor de comunicare. Responsabilitatea pe care o are în lume Biserica lui Hristos este determinantă pentru o comunicare în duh si adevăr, nu trebuie îndepărtat de acest lucru utilizarea corectă a acestor mijloace de comunicare. Utilizarea corectă a acestor instrumente depinde în primul rând de cel care le utilizează, de modul de cunoaștere al efectelor negative care pot fi cauzate de o folosință necorespunzătoare. Biserica este și trebuie să fie mereu un organism viu, membrii acestui Trup tainic trebuie să fie cu multă luare aminte în ceea ce privește digitalizarea vieții, pentru 
că tehnologia a pătruns astăzi în toate manifestările acestora: muncă, informare, educație, prietenie, relații interumane și în alte domenii. Toate acestea schimbă identitatea persoanei, dincolo de demnitatea ei reală aceasta primind o dimensiune virtuală. ${ }^{19}$

Valorile sunt foarte diversificate şi aproape fiecare persoană are tendinţa de a le adapta, chiar dacă multe dintre ele sunt lipsite de coerenţă. În felul acesta, se naşte un fel de Turn Babel în lumea occidentală şi este foarte greu să comunici şi să te confrunţi în acelaşi timp. Astăzi nu mai există nici o graniţă între comunicare, cultură sau sociologie, economie pentru că de foarte multe ori acestea se confundă între ele. Putem afirma că sistemul de valori se schimbă extrem de rapid: ceea ce astăzi funcţionează, mâine s-ar putea să nu mai meargă. Trăim într-o epocă fascinantă, dar în acelaşi timp dificilă şi caracterizată diferit. Mijloacele media ne poartă în aproape toată lumea, mijloacele de transport au redus distanţele, internetul ne pune în contact cu toate persoanele, informatica ne pune în dificultate şi, de foarte multe ori, confundăm ceea ce este real cu ceea ce este virtual, într-un cuvânt se schimbă în permanenţă conceptul de timp şi de spaţiu. Este pentru prima dată când lucrurile acestea s-au infiltrat perfect în cursul umanităţii.

Fiecare lumină are umbra sa, astfel și noile tehnologii, dincolo de ușurința cu care putem transmite o informație, lasă deschisă o poartă foarte largă pentru multe capcane de rețea. Nu trebuie să uităm cuvântul Sfintei Scripturi care ne îndeamnă să fim cu luare aminte la toate lucrurile din lumea aceasta, lucruri bune, dar nu toate de folos sau îngăduite.

${ }^{19} \mathrm{Cf}$. Pemptousia, Conferința Media digitala și pastorația Bisericii, Atena mai 2015. 


\section{Bibliografie:}

1. Adriano Zanacchi, Pubblicita, Effetti Collaterali, Roma, Editori Riuniti, 2004.

2. Giorgio Triani, Il futuro e adesso, Societa mobile e istantocrazia, Torino, Edit. San Paolo, 2013.

3. Franco Lever, Pier Cesare Rivoltella, Adriano Zanacchi, Nuove Tecnologie della comunicazione, in „Dizionario di scienze e tecniche", Elledici, Rai, Eri, Roma 2002.

4. Jacques Ellul, The Technological System, New York, Contunuum Publishing Corportaion, 1980.

5. P. Greco, Cibo per la mente, newsletter di Fondazione IDIS Citta della Scienza, 16 ottobre, 2012.

6. Manuel Castells, Galassia Internet, Saggi Universale Economia Feltrinelli, 2006.

7. Pr. Conf. Teofil Tia, Globalizarea- elemente de Teologia Economiei, Alba Iulia, 2009.

8. Pemptousia, Conferinta Media digitală și pastorația Bisericii, Atena, mai 2015.

9. F.B. Thompson, Mezzi di comunicazione e modernita, Il Mulino, Bologna.

10. Ro.wikipedia.org/wiki/limba_sintetica.

11. Unesco, congresul, Blog și blogger în lumea în mișcare, Marsilia, 3 martie 2012. 